\title{
Him Too? Cristiano Ronaldo and the News Coverage of a Rape Case Allegation
}

\section{Maria João Silveirinha, Rita Basílio Simões \& Thâmara Santos}

To cite this article: Maria João Silveirinha, Rita Basílio Simões \& Thâmara Santos (2019): Him Too? Cristiano Ronaldo and the News Coverage of a Rape Case Allegation, Journalism Practice, DOI: $10.1080 / 17512786.2019 .1693279$

To link to this article: https://doi.org/10.1080/17512786.2019.1693279

曲 Published online: 20 Nov 2019.

Submit your article to this journal

Џ Article views: 28

Q View related articles $₫$

View Crossmark data \lceil 


\title{
Him Too? Cristiano Ronaldo and the News Coverage of a Rape Case Allegation
}

\author{
Maria João Silveirinha (1D ${ }^{a}$, Rita Basílio Simões (1D ${ }^{a}$ and Thâmara Santos (1D ${ }^{b}$ \\ a'Departmento de Filosofia, Comunicação e Informação, Faculdade de Letras, Universidade de Coimbra, \\ Coimbra, Portugal; ${ }^{b}$ Instituto Federal do Tocantins, Universidade de Coimbra, Coimbra, Portugal
}

\begin{abstract}
This paper uses critical thematic analysis to explore the news media coverage of a rape allegation case against the football player Cristiano Ronaldo. After providing the context of the case, we examine the literature on how rape cases are represented by the news media. We then proceed to a critical thematic analysis of a purposive sample of Portuguese national newspapers, first identifying ten sub-themes in a total of 140 news stories and opinion columns and then considering the patterns of three critical themes that tended to dismiss the allegations, highlight the seriousness of the allegations and neutralize sexual victimization. Each of these considers prevailing ideologies, news values and journalistic practices.
\end{abstract}

\section{KEYWORDS}

Rape allegations; sexual violence; news coverage; thematic analysis; critical thematic analysis; celebrities

\section{Introduction}

In 2017 the revelations of the Harvey Weinstein case echoed across the international media landscape, causing public outrage and uniting women around the \#MeToo movement. This has helped a heightened visibility of sexual violence in the public domain but, as Alcoff (2018) has argued, the political effects of this increased visibility have been highly variable. Thus, the need to be attentive to local contexts, to situated political demands for justice, to the way some victims' stories are deemed more believable than others are important tasks in evaluating the real impact of rape visibility. Indeed, as numerous cases show, the outrage started by the \#MeToo movement does not always come to force when it comes to sexual offense committed, for example, by some famous people. Likewise, rape complaints do not always mean the end of the perpetrator's popularity and indeed often a highly public or celebrity status tends to protect the accused through disbelief of the accuser in the public eye.

With this in mind, we approach the case of the Portuguese and international celebrity football player Cristiano Ronaldo who was accused, in a September 2018 civil lawsuit, of sexual assault by an American woman. The story made international headlines, but it was particularly focused by the Portuguese media. In a country where Cristiano Ronaldo is a very important and visible national sports icon and national hero- "the only consensual hero of present times, the role model for determination, the nation's pride ${ }^{\prime 1}-$, the 
news first reported by a German news magazine soon hit the local press, bringing the issue to the nation's attention and sparkling a furious stream of comments in social media (Silveirinha and Simões 2019).

This paper is concerned with how rape ideas come to exist, as ideologies intercept each other in news discourses. We wanted to explore how the national news covered the rape allegations and how celebrity as a news value can become an important determinant for covering rape cases. More specifically the questions that guided the research were: When the rape allegations were discussed in the news, how seriously were they taken? How did the news relate the status of the accused and of the complainant? How did the news relate to gender ideologies and understandings of rape?

Taking as the starting point the importance of adopting a feminist approach to studying mediatized representations of rape, the research of this case provides a critical thematic analysis of the ways that news media interpret and construct an ongoing case of rape allegations. The paper outlines an integrated model of rape themes in the news that includes a set of sub-themes which are then aggregated into a smaller number of critical themes articulating the interrelationships between news discourses, power relations and ideologies.

\section{Rape Allegation Against Cristiano Ronaldo}

The case started in 2009, when the American citizen Kathryn Mayorga reported a rape to police, without identifying her attacker by his name. She was taken to a local hospital, where she was examined. Later, Mayorga's lawyers and the representatives of the Portuguese football player and international celebrity Cristiano Ronaldo signed an out-of-court settlement. Both parties agreed to not discuss the details in a non-disclosure agreement, and Ronaldo's team agreed to pay Mayorga a certain amount of money. ${ }^{2}$

Eight years later, the German news magazine Der Spiegel ${ }^{3}$ first published a report about the accusations of rape against the Portuguese celebrity. In it, Mayorga was identified as "Susan K" to preserve her anonymity. In September $2018^{4}$, a year and a half after Der Spiegel's first story, Mayorga decided to reveal her identity and tell her side of the story to the magazine. Ronaldo's lawyer defined the story as "blatantly illegal" and threatened to seek compensation from the news magazine. ${ }^{5}$ Soon after, Mayorga's new lawyer claimed that she had inadequate representation in 2009 and 2010, and was bullied into settling. She then filed a lawsuit in Nevada, accusing Ronaldo and his team of taking advantage of her emotional state and coerce her into signing a settlement and nondisclosure agreement, therefore seeking to void the settlement and agreement. ${ }^{6}$ Las Vegas police confirmed that they investigated a rape complaint in June of 2009, but could not follow through because the victim did not provide the location of the incident or suspect description, but in face of Mayorga's willingness to give details, they reopened the case. ${ }^{7}$

Ronaldo himself first disputed the claims in an Instagram live post in October 2018 with the following statement:

What they said today, fake ... fake news. They want to promote themselves by using my name. It's normal. They want to be famous ... to say my name. Yeah, but it's part of the job. I'm (a) happy man and all, all is good. 
He also wrote on Twitter:

I firmly deny the accusations issued against me. Rape is an abominable crime that it goes against everything that I am and believe in. Keen as I may be to clear my name, I refuse to feed the media spectacle created by people seeking to promote themselves at my expense.

This was not the first time Ronaldo faced this type of allegations. He had already been questioned in October 2005, after himself and his cousin were accused of raping two women. However, this London-based rape allegation was ultimately dropped by Scotland Yard, as The Crown Prosecution Service ruled there was insufficient evidence to push ahead with a prosecution. ${ }^{8}$

Recent events, however, caught the national media attention in unprecedent ways that this research seeks to understand. As we shall see in the next sections, two reactions from Portugal's highest political leaders expressed an opinion that the country's news media were already conveying: we should trust the "national hero". Indeed, the Portuguese Prime Minister was the first to speak out in defence of the football star, making an appeal to presumption of innocence, and stressing out Ronaldo's successful career. The nation's President also came in defence of the "national hero" saying he would not change his mind about Ronaldo's sports role in the life of the country simply because he was involved in a rape case allegation. To answer them, we first turn to what previous research of similar cases tells us.

\section{Literature Review}

\section{Rape Genres and Celebrities}

Research has long established that the media is inaccurate in its portrayal of violence against women, including sexual violence (Benedict 1992; Soothill and Walby 1991). A large body of work on reporting of rape and representations of women as rape victims shows that these have historically been presented by the news media in a misinformed manner, influenced by myths and misconceptions about the dynamics of sexual violence. The media have been found to blame victim-survivors of rape, create excuses for perpetrators (Meyers 1997; O'Hara 2012; Waterhouse-Watson 2016, 2019).

But research has also provided us with the insight that not all rape cases are the same in the media. In the words of Alcoff (2018), some stories of sexual violence are more "palatable" than others. This difference is built for example, as Nilsson (2018) has shown, through different "rape genres". These are enacted as "news coverage of rape produces different genres by identifying societal 'problems,' apportioning 'blame' and suggesting 'solutions'"(Nilsson 2018, 14).

One of these genres is the "celebrity rape", one where "the need to maintain the state of cultural anesthesia is, more than in any other genre, explicitly expressed" (Nilsson 2018, 10). We also see different attributions of blame and sympathy by the media in rape cases according to key features of the men and women involved, such as their race, their social class and social status (Ardovini-Brooker and Caringella-MacDonald 2002).

Indeed research has given us a number of important insights into the media coverage of several high profile cases of rape, including the work by Waterhouse-Watson (2013, $2016,2019)$ on Australian athletes, Kathryn Royal's research (2019) on a rape case involving 
a British footballer, Franiuk et al. (2008) study of headlines on the trial of a Laker's star athlete.

Harrington (2016) research of the news and commentary on rape accusations of Julien Assange as an international celebrity was particularly useful for our research as there were some similarities in the way the issues of Assange and Ronaldo were reported and discussed in the media. Her analysis first separated the thematic codes into: (a) a set of themes deployed to dismiss the allegations, which included, among others, themes of a heroic fugitive, positive reporting on devoted supporters, accused innocence, trivializing the allegations, women scorned/scrutiny of the complainants and (b) themes deployed to highlight the seriousness of the allegations, including the allegations amount to sexual violence, condemning media attacks on complainants and condemning rape myths (Harrington 2016, 92).

These cases show that the status of the accused prompts significant attention from the media, driven by the fame. This is particularly true of well known and loved national athletes, such as the case of the Portuguese footballer Ronaldo that we uncover here. In the words of Waterhouse-Watson (2016, 1), "Footballer sexual assault cases are particularly important, as elite athletes are held in high public regard, and the wide media coverage afforded them is likely to be significant in shaping public perceptions of specific cases, and rape in general". Likewise, Cuklanz $(1996,37)$ argued that the publicity that rape cases offer allows feminist perspectives to be put on the public agenda. Yet, the very public status of these men also tends to hinder this opportunity, exemplifying how power differentials between men and women are played out in the public arena. In the case of celebrities, these power differentials correspond to the double standards placed on the famous men who can feed their admiration into rape myths to escape accusations in the public mind, versus the anonymous women who are positioned in these rape myths as the deserving victim (Nyúl et al. 2018).

To understand these representations we have to take into account that all media representations are not only informed by dominant social attitudes and external factors such as police and court procedures but that they are also "framed by internal media dynamics including institutional racism and sexism within the media industries, news values (such as the search for the sensational) and journalistic practices (such as the impact of tight deadlines)" (Kitzinger 2009, 74). Thus, a case involving a national popular figure not only also provides links to the national imaginaries of heroes and foes but is particularly newsworthy.

It is also important to understand to what extent the case affected Cristiano's public representation. In studying Portuguese young people's celebrity culture, Jorge (2015, 11) points out that although Ronaldo's athletic talent is undisputed and even worshipped, "class judgements are more intense around the global scope of the football player's celebrity, considering his social origins". This is because $(2015,11)$, "national celebrity culture is more associated with an attributed status, whereas foreign and global celebrity is seen as achieved and thus more worthy". The rape case would allow us to see how this celebrity status played out in the case news' coverage.

Finally, Weiss (2011) also provided us with a typology of accounts used by victims to neutralize sexual victimization: denying criminal intent, denying serious injury, denying victim innocence, and rejecting a victim identity. While this typology concerned the 
accounts provided an effective rationale for victim's non-reporting, it gave us important insights into accounts of sexual crimes.

\section{From Rape Myths to Media Coverage}

Rape myths, such as "women want to be raped", "women deserve to be raped", "women provoke rape", and "women enjoy being raped" are long-standing cultural narratives inherent to the mythology of anti-women violence and victim blaming ideologies. But these myths have deep consequences for the criminal justice system and to the way sex crimes are judged by the public.

A common base for these myths is ideas about men and women's sexual agency, which take us beyond the issues of women's volition, free choice and individual autonomy (Reynolds 2015) to a domain where women's sexual choices are entirely free from violence. As Baker and Oberman $(2016,64)$ put it: "When two people have intercourse consensually, what happens is sex. When there is not mutual consent, what happens is rape". Women can face rape's "double jeopardy" in which she is scrutinized for the veracity of her story, in terms of her perceived character, her sexual history, mode of dress or attitudes which may be seen as contextual to rape.

Myths about rape have developed in the legal and popular culture against the background of beliefs characteristic of patriarchal culture. Over time, these myths embodied in law, in rape trials and in the narratives of news and entertainment media reified the white male middle-class perspective on rape. Also, as Horvath and Brown (2009) remind us, research sometimes uses the term "real rape" (or "stereotypical rape") to refer to the widely held belief that genuine rapes contain a number of elements-such as the victim and rapist are strangers; the assault occurs in an outdoors location; the victim shows active visible resistance; and the rapist uses or threatens to force the victim. This also feeds into the rape myths often conveyed by the media. As Kitzinger (2009) shows, this can be seen in how the media continue to reinforce and perpetuate the notion of "real rape" through their selective reporting of serial rape or especially violent rapes. If a rape allegation such as the one discussed here does not fall into these categories, its newsworthiness lies elsewhere: in the public status of the accused.

In order to better understand how media contexts may reinforce the use of rape myths, we should take into account feminist critiques of rape and of the media. In this respect, Kitzinger (2009) reminds us that The Women's Liberation Movement played a key part in the increasing recognition of sexual violence. It set the path for how second wave feminists "re-envisaged rape and sexual abuse as a symptom of a culture of violence against and disrespect for women, which should be viewed as a form of sexist hate crime (rather than an impulsive act of sexual need)" (Kitzinger 2009, 95). Sometimes the media followed the feminist lead and produced good reporting of rape, with an important impact on the social and political recognition of the problem.

Mendes, Jessica, and Keller (2019) also remind us of the importance of naming "rape culture" as a term coined by feminists in the United States in the 1970s to show the ways in which society blamed victims of sexual assault and normalized sexual violence against women. The term also highlights the sexual double standard of privileging male sexuality while limiting women's sexual agency. Rape culture is embedded within social 
and cultural practices such as the ones the authors (Keller, Mendes, and Ringrose 2018, 24) describe:

[R]rape jokes, sexual harassment, cat-calling, sexualized "banter"; the routine policing of women's bodies, dress, appearance, and code of conduct; the re-direction of blame from the perpetrator in an assault to the victim; and impunity for perpetrators, despite their conduct or crimes.

Some media practices are embedded in this very same culture, contradicting the gains in changes in media coverage in terms of the extent of attention, and some reform of its coverage of rape. Once again Kitzinger $(2009,96-07)$ points out a number of interrelated areas in which the media in general, or certain segments of the media, are open to criticism. These include, among others, the "events-based" emphasis of news reporting, the focus on controversial allegations, the objectification of victims, relying on court-based discourse, excusing perpetrators and perpetuating stereotypes about victims and victimization, selective cultural explanations of rape.

\section{Methods}

The dataset is distilled from a corpus of news articles and opinion columns about the rape allegations against the Portuguese football player Cristiano Ronaldo by the American citizen Kathryn Mayorga.

The collected material consisted of three manually filtered purposive samples of news stories and opinion columns from the three most widely read Portuguese Newspapers ${ }^{9}$ : two popular daily papers-Correio da Manhã and Jornal de Notícias-and one influential weekly publication-Expresso. These newspapers are owned by national media conglomerates. Following the national tradition, they do not position themselves clearly in either side of the political spectrum and tend to be generally considered as center-liberal. Correio da Manhã's articles were obtained from the LexisNexis database. The texts from the other two papers (non-existing in LexisNexis) were retrieved from the newspapers' own digital archives. Online versions of the newspapers often do not show sections and given these disparities, sections were disregarded.

All content was searched through the string "Ronaldo and Mayorga" and all texts that mentioned Ronaldo and Mayorga from September 2018, when Mayorga rape allegations were formalized, until May 2019, when coverage tapered off, were retrieved-a total of 145 news and opinion items.

These search results were checked, and after a first reading of all the articles we put aside those which only briefly mentioned the case. We ended up with a total of 140 news items. The unit of analysis employed was the news article and the opinion article.

Table 1. Newspapers and articles data set.

\begin{tabular}{lccc}
\hline Newspaper & $\begin{array}{c}\text { News stories } \\
(N=130)\end{array}$ & $\begin{array}{c}\text { Opinion columns } \\
(N=10)\end{array}$ & $\begin{array}{c}\text { Total } \\
(N=140)\end{array}$ \\
\hline Jornal de Notícias & $51,43 \%$ & $0,72 \%$ & $52,15 \%$ \\
Expresso & $24,28 \%$ & $6,43 \%$ & $30,71 \%$ \\
Correio da Manhã & $17,14 \%$ & - & $17,14 \%$ \\
\hline
\end{tabular}


As showed in the Table 1, the search yielded 130 (92,8\%) news stories and $10(7,2 \%)$ opinion columns, all included for analysis. As Stig Hjarvard $(2010,25)$ reminds us, "according to professional journalistic norms, news and views must be separated, but in actual practice the borderline may not always be clear, and in the minds of some readers it may not even be desirable". Together, they give us a broad insight into how the issue was covered by the newspapers, providing, in a wider sense, interpretations of the social and cultural world.

After a second close reading of the sample, an inductive-deductive coding was carried out by the three researchers who worked together in order to identify the predominant themes in the texts, based on the research questions and the existing literature and embracing feminist research principles such rereading, deconstructing and reconstructing texts in terms of what they say and do not say about women and paying attention to their manifest and latent meanings (Reinharz 1992).

The coding procedure followed Lawless and Chen (2019) who developed a method for critical thematic analysis. Because feminist analysis is grounded in an understanding of fundamental power differentials, we took this version of thematic analysis to be particularly suited to examine the interrelationships between news discourses, power relations and ideologies.

The coding was divided into two distinct stages. First, guided by Owen's (apud Lawless and Chen 2019) thematic analysis criterions, we identified patterns of recurrent, repeated, and/or forceful discourses. This "open coded" stage allowed us to identify emergent themes some of which coincided with previous research, having therefore been adopted (Harrington 2016; Weiss 2011). These themes were refined iteratively and new themes emerged inductively.

We next systematically performed a "close coding" (Lawless and Chen 2019) of texts, interrogating how our body of ten initial themes ${ }^{10}$, intersected larger societal ideologies, patriarchal values and institutional structures in newsrooms. In this final stage were produced three broader critical themes and ten subthemes, that articulate ideologies, values and news practices, as showed in the Figure 1.

\section{Results and Discussion}

Collectively, news media themes shape how rape ideas come to exist, as ideologies intercept each other in news discourses. As explained above, our analysis produced three overarching critical themes binding together rape allegations, gender ideologies and mythological ideas about rape and status of individuals.

These three critical themes were partly inspired by Harrington (2016) who also studied a rape case involving a national celebrity. The three overarching themes aggregated the first level sub-themes as follows: The first critical theme was deployed to dismiss the allegations. This included the following sub-themes: Ronaldo is innocent; Ronaldo's celebrity status and national hero; trivializing the allegation; and scrutiny of the complainant. Secondly, we found a critical theme deployed to highlight the seriousness of the allegations, which included the sub-themes of: scrutiny of the accused, complaint vulnerability and deconstruction of rape myths. Finally, a third critical theme was identified as leading to neutralizing sexual victimization. This included the sub-themes of: economic consequences, collateral damages and case events. We look into their details in the following paragraphs. 


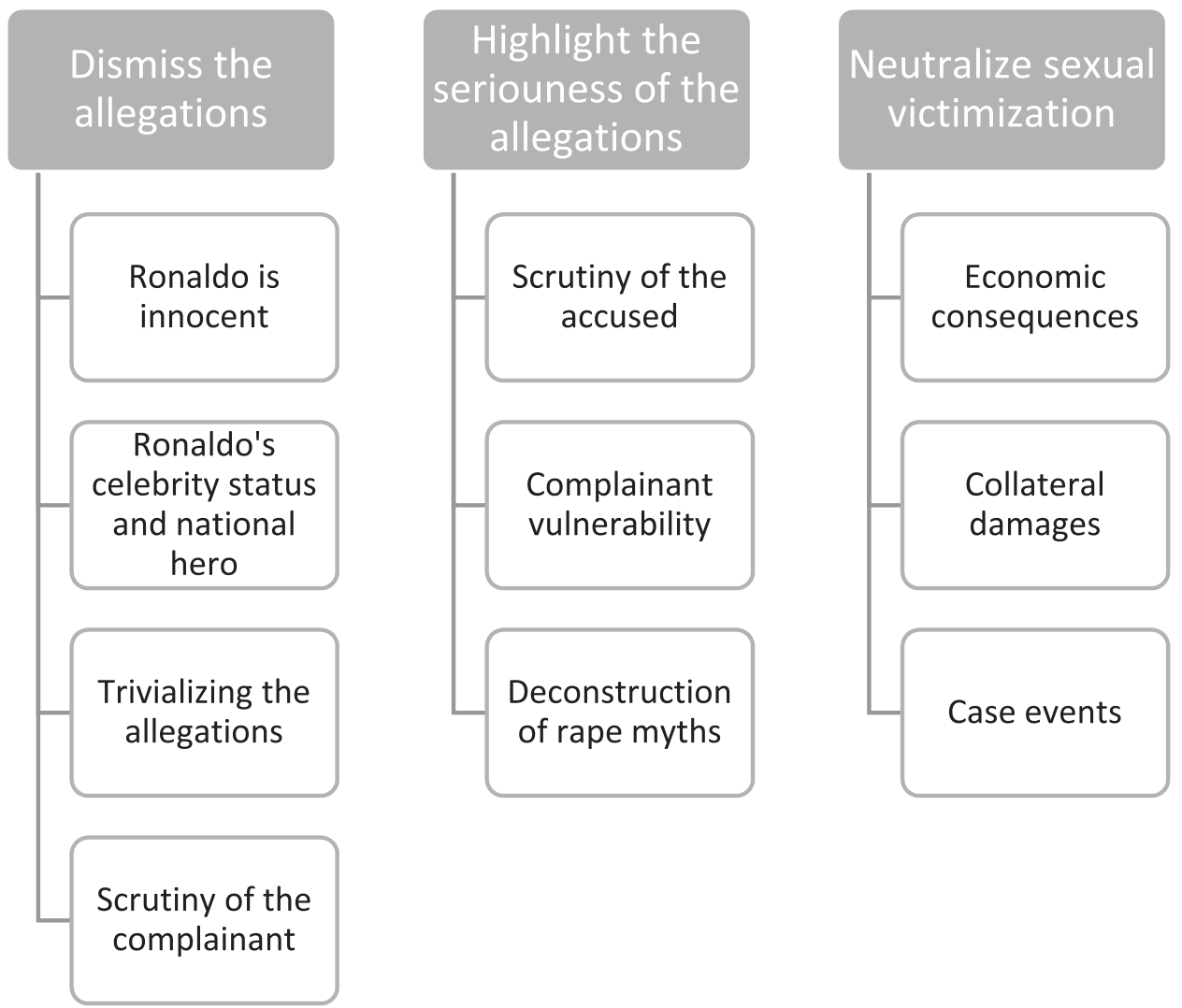

Figure 1. Critical themes and sub-themes.

\section{Themes Deployed to Dismiss the Allegations}

Most reporting on the allegations happened in October 2018, following the publication by the German magazine Der Spiegel second story about the case. Soon after, Portuguese press gathered around Ronaldo's innocence as stated by quoted information sources. From his lawyer, threatening to seek compensation from the German news magazine, to public and political figures, including the Portuguese President of the Republic, claiming Ronaldo was a national hero, the allegations of rape were hardly accepted as legitimate: Cristiano Ronaldo was found "innocent" in the "public trial". Overall, one in four news items dismissed the allegations, making up the most frequent sub-theme of the sample, Ronaldo is innocent.

The Portuguese Prime Minister, António Costa, defended the football player by making an appeal to the presumption of innocence, and by pointing out Ronaldo's successful career: "Being accused of something does not make someone guilty" (Expresso, 6 October). Both Expresso and Jornal de Notícias quoted this statement. Jornal de Notícias ran a story uncritically reporting what the Prime Minister actually did: António Costa defended the presumption of Ronaldo's innocence but did so highlighting the player's status of a national hero: 
If there's something we have proof of is of how an extraordinary professional, an extraordinary sportsman, an extraordinary footballer he is, as someone who has honoured and given prestige to Portugal, and we certainly all wish nothing ever stains such a record of Ronaldo. (Jornal de Notícias, 6 October 2018)

Such statements around Ronaldo's innocence were recurrent by his immediate family and friends' quotes in the press. Thus, the press gave full voice to his mother, Dolores Aveiro, a popular figure in social media. She asked Ronaldo's fans to establish a "chain in his name", in the name of "Portugal" and in the name of "justice".

"I want to see who has the courage to put this photograph in the profile for a week and make a chain for him ... For Portugal, for him, for us, for the union of the people ... For justice. He deserves it", wrote the matriarch of the Aveiro clan in her first reaction to the accusations of her son by Kathryn Mayorga, with whom CR7 would have been sexually involved with. (Jornal de Notícias, 8 October 2018)

Having creating the hashtag of support-"Ronaldo we support you till the end",-Dolores Aveiro was referred to as the mentor of a "movement" which rapidly joined "thousands of people in social networks" in defence of the player, as reported by Jornal de Notícias. (9 October 2018). Among the "participants", there were popular figures such as the singer Tony Carreira, whose posts about the case also made the news:

"It's not a matter of courage to share this 'post'. From what I know of Cristiano, I do not believe this accusation and until otherwise established, he is innocent", said the singer. (Jornal de Notícias, 9 October 2018)

Coverage also included quotations by other supportive entities, such as the Italian brand of underwear Yamamay, for which the footballer had modeled. Correio da Manhã reports, quoting the brand:

We are in the middle of the campaign, we have not changed our investment plan and we continue our advertising plan, which is going very well. We believe that we have to preserve the presumption of innocence. (Correio da Manhã, 6 October 2018)

The unreliability of the complainant testimony is a widespread cultural belief repeatedly shown by academic rape research (Benedict 1992; Cuklanz 1996; Gray 2015; Temkin, Gray, and Barrett 2016). This occurs frequently in popular discourses by making the aggressor's actions invisible and by highlighting the complainant' character and flaws. In this case, however, Ronaldo is not only visible and publicly defended, but also celebrated as a global celebrity.

Another sub-theme working towards dismissing the allegations is precisely what we coded as Ronaldo celebrity status/national hero, making up $8 \%$ of total texts. In them, the football player is galvanized and heroized, regardless of direct or indirect innocence allusions.

We could see this sub-theme clearly being articulated in the press through quotes of the President of the nation, claiming Ronaldo as a "national hero":

The President of the Republic said this Friday that football player Cristiano Ronaldo will always have a national and sporting role despite his "involvement in criminal justice" for alleged rape of an American woman. (Correio da Manhã, 5 October 2018)

Ronaldo's heroic status is also made visible in the lexical options characterizing him. He is: 
A reference for thousands of children and teenagers all over the world

[V]ery much in touch with his fans, especially the youngest ones, who follow all his steps in the social networks. (Correio da Manhã, 14 December 2018)

Embowed in this sympathetic intertextuality is also Ronaldo's self-presentation cited by the papers:

"I know I'm a role model, inside and outside the field. That's why I'm always smiling (...)", said the Juventus' striker. (Correio da Manhã, 22 October 2018)

Although, from a news value perspective (Gans 1979), Ronaldo's notoriety justifies the media interest in his personal life, the reporting of his public appearances following the allegations highlighted not only his glamourous style, but also his immunity to the accusations:

All controversy aside, the player amused himself at the sound of American Jason Derulo. (Jornal de Notícias, 15 October 2018)

The earrings are one of his trademark images, but Cristiano Ronaldo has managed to add even more brilliance to his look. The occasion could not have been better. This Monday, the day he first presented himself to journalists after being accused of rape, the Juventus striker emerged smiling and flaunting two luxury accessories. (Jornal de Notícias, 23 October 2018)

Also, if Ronaldo's celebrity status is ambiguous in other media spheres, as Jorge (2015) shows, in the context of this case his status is not only unambiguous but also clearly a determining factor. This is in line with other analysis of rape cases involving top athletes, which emphasize celebrity as a crucial element for a sympathetic constructing of the defendant's character (Royal 2019; Waterhouse-Watson 2013, 2016). Deb WaterhouseWatson $(2013,35)$ argues that this functions as "narrative immunity" against being held accountable for sexual assault: "the mere fact that the alleged rapists are well-known footballers, and the alleged victims anonymous women, puts the complainants at an immediate disadvantage in terms of being believed".

Trivialization of the allegations is another sub-theme that reproduces patriarchal values in reports. One in ten news items shows discursive patterns which serve to deny the Der Spiegel's coverage of the rape accusations, emphasizing the case documents' incongruencies and stressing the fragility of the case which is often referred to as "polemic" and "controversial".

The US lawyer representing the national team's captain Peter Christiansen said last Wednesday that "the documents containing Mr. Ronaldo's statements, reproduced by the media, are pure inventions", adding that "they were stolen by cybercriminals and that significant parts have been altered and/or manufactured", in a reference to the contents cleared by "Der Spiegel". (Expresso, 13 October 2018)

The theme is also built by downplaying the story. This is accomplished by naming "sexual involvement" the experience defined by the complainant as sexual aggression. In opinion columns, this theme is constructed through the idea of a "witch-hunt", following the Me-Too movement. Some commentaries contest the rape allegations against Ronaldo as not being about justice, but as about power. As one commentator stated: 
Many women have extraordinary power over men. And it does not matter that years that have passed; whether it has been consented or not; whether they were in their right mind or not. As is seen in the Kavanaugh case, the word of the woman in these cases prevails over that of men, because men are seen as predators. (Expresso, 3 October 2018)

Other news items focus on peculiar and/or biting details and events, exploring the rape allegations. We see this, for example, in the news about a Portuguese shop in the United Kingdom which "makes controversial 'Cookies Ronaldo'". We read in the news that the shop owner, inspired by the judicial case, created cookies in the shape of simulated anal intercourse.

Ironically, this Tuesday was the bestselling day in the shop which was opened four years ago by the Portuguese citizen, having been visited by many locals searching for the controversial cookies. "They wanted to buy them (...) but because the cookies were finished, they ended up drinking coffee and buying cream pastries", he said. (Jornal de Notícias, 16 October 2018)

The final sub-theme building up to dismiss the allegations is that of scrutiny of the complainant. The belief that women provoke and deserve rape and that only lost women or play girls are abused is a commonly documented rape myth that works to deny or justify aggressive sexual behavior (Benedict 1992). Discursive patterns that emphasize the complainant's behavior flaws (dress mode, social behavior, drinking) are only residual in our sample. We can, however, identify them in the items where Mayorga is not represented as the complainant or the "alleged victim", but as the "accuser", an extra-legal term with negative connotations as pointed out by Kathryn Royal $(2019,93)$.

Model accuses Cristiano Ronaldo of rape. (Correio da Manhã, 2 October 2018)

The undermining of Mayorga's credibility is also found in news that focus Ronaldo's' immediate family statements in social media posts, interpreting the complaint as false and as a way to obtain money:

This Saturday Katia Aveiro once again defended her brother from the accusations of rape charged by the North American Kathryn Mayorga, with whom Cristiano Ronaldo became sexually involved in June of 2009. The day after writing on social networks "some $p^{* * * *}$ [sluts] want to win in life at the expense of other people's money", CR7's sister insisted on the idea, publishing a passage from the Bible as a caption for two images of Cristiano. (Jornal de Notícias, 6 October 2018)

\section{Themes deployed to highlight the seriousness of the allegation}

Our second critical theme, deployed to highlight the seriousness of the allegations, is much smaller in the sample. From a feminist perspective, only by taking sexual assault complaints seriously can the patriarchal cultural be challenged, including the beliefs that contribute to justifying the aggressor and maintain a "victim-whore" dichotomy. Responsible reporting about rape will frame the story as violence against women, reject the blaming and the sexualisation of the complainant and avoid media reporting which reinforces negative gender stereotypes (Benedict 1992; Royal 2019).

In the sample, only $15 \%$ of the items highlight the seriousness of the allegations by scrutinizing the accused, deconstructing rape myths or emphasizing the complainant's vulnerability. Ronaldo's scrutiny as a perpetrator is the main theme of three opinion columns, 
where his "moral character" is questioned. One of these articles asks us "not to deify Ronaldo":

(...) it must be clearly said that Ronaldo is only a football player, he is not a moral example for anyone. Incidentally, Ronaldo is quite questionable as a public figure, as a "model" of off-field behaviour. (Expresso, 20 March 2019)

Differently, news articles where Ronaldo's scrutiny is the theme highlight "Ronaldo's contradictions about alleged violation":

Cristiano Ronaldo's original responses on rape and differences between September and December Player confession was deleted from the email sent to Mayorga's lawyers and a new one was created. (Correio da Manhã, 2 December 2018)

Mostly seen in opinion texts, the deconstruction of rape myths is also found in six news items. One of them ran the headline "Marialva's Patriotism" ${ }^{11}$ which links the structural national machismo with the overall reactions to the case:

The Ronaldo-Mayorga case reveals how Portuguese patriotism only rips open in defence of machismo and under the notion of Marialva's decency, "She was asking for it!". One thing is the presumption of innocence. Something quite different is what we have seen. From the men in taverns to the President, the attitude has been: there is no presumption of innocence, but absolute certainty that the national hero is innocent. (Expresso, 10 Ocober 2018)

Seven other articles deployed the seriousness of the allegations in a different way-by emphasizing the complainant's vulnerability and not her doubtful credibility.

It was not just the police who advised Kathryn Mayorga to file a complaint of rape against Cristiano Ronaldo. The nurse who conducted the first forensic examinations after the night that the former model and football player met at The Palms Place Casino Resort in Las Vegas, USA, also told the American woman that she would be subject to "retaliation and publicly humiliated" by the now Juventus player. (Jornal de Notícias, 10 October 2018)

\section{Themes Deployed to Neutralize Sexual Victimization}

The third critical theme- neutralizing sexual victimization-is observed in about one third of the sample. To establish it, we followed Weiss (2011) who refers to victim's, as well as offender's accounts of sexual crimes, as neutralizing sexual victimization as part of their definitional negotiations that take place following victimization. In our understanding, the news media can also neutralize sexual victimization in as far as they shift the focus away from sexual assault and prioritize the case details as news events (for example, lawyer's statements or legal details of the case) or the collateral effects and unintended consequences of the sexual assault claim. By establishing the main themes of these news as collateral damages and consequences or even as simple events around it, the media displaces or neutralizes the sexual assault allegation, its perpetrator and its victim. Also, this kind of coverage has a similar function to what Kathryn Royal $(2019,94-96)$ calls a distraction from the perpetrator and the crime.

Twenty articles neutralize sexual victimization by focusing the case events, such as the US legal procedures, actions from the prosecution and from the defence, speculation about missing evidence and other incidents with news value. 
Against the backdrop that journalism is simply "the promulgation of facts" and the conveying of "objective events", the sociology of news has long shown how professional ideology is made of institutionalized procedures, such as the use of powerful sources (Hall et al. 1978) and of "strategic rituals" to convey objectivity (Tuchman 1978), reproducing society's ideological structure. From a feminist perspective, the typical "events-based" emphasis of news on sexual violence rather than on the issue is particularly problematic, because, as Kitzinger (Kitzinger 2009, 98) pointed out, it is "implicitly" presented "as a taken-for-granted fact of life, with the emphasis placed on intervention and judgment in particular accusations rather than broader social solutions".

The case was reported as extraordinary, but only because of its economic consequences, another sub-theme that neutralizes the sexual victimization. The number of the crimes involved in the complaint and the amount of the "required" compensation are indeed repeatedly explored.

Eleven crimes and 174 thousand euros (200 thousand dollars). This is the complaint and the compensation amount requested by Kathryn Mayorga (...), the north-American who has just accused Cristiano Ronaldo of having raped her in Las Vegas in 2009. (Jornal de Notícias, 4 October 2018)

Another way of emphasizing the side effects is by focusing the lost and gains of third parties, specially of the football club Juventus and the brands which Ronaldo has financial contracts with. Equality, the attention is directed to events, in this case events affected by the case, and not the incident, the alleged survivor or the alleged aggressor.

Juventus's shares have continued to fall since US-born Kathryn Mayorga accused Cristiano Ronaldo of alleged rape. (Jornal de Notícias, 9 October 2018)

Jeep campaign with Juventus players without Cristiano Ronaldo. (Jornal de Notícias, 5 October 2018)

Another way of distracting from the rape incident and the issue of sexual violence can be observed in the sub-theme collateral damages. Far beyond contextualizing rape as men's violence against women, $12 \%$ of the sample detours from the case to talk about its side effects, as seen in the news about Juventus leaving pre-season in the USA "to protect Cristiano Ronaldo" (Expresso, 21 March 2019). Other types of collateral damages were also observed. This is particularly the case of a group of news concerning a post about sexual violence that the director of one of the Portuguese public television channels (RTP), Paulo Dentinho published in Facebook. There, he put forwards the argument that the "status" of rapists influences the judges about the victims. Such post led to his leaving the national TV station (Jornal de Notícias, 5 October 2018). His argument about the suffering of rape victims was not framed as progressist thinking but rather as a professional flaw, because that it referred to Ronaldo's case, taking the complainant's side.

\footnotetext{
"There are first, second, third category raped women. It depends on their status but, above all, on the rapist's status", Paulo Dentinho wrote on his personal page in Facebook last Thursday afternoon. "And if the rapist has the national hero's halo, she is a $p^{* * *}$ [slut] for sure or in the least a vamp with no scruples at all," he continued. "The facts, $f^{* * * *}$ the facts. She was asking for it, that's what it was", added the director of RTP. (Jornal de Notícias, 5 October 2018)
} 


\section{Conclusion}

A considerable body of work has studied the representation in news of highly visible cases of allegations of sexually violent crimes by male athletes or celebrities. In general, this previous research criticises representations as evoking woman-blaming stereotypes, such as the "gold digger" woman and deflect blame away from athletes and onto complainants (e.g., Waterhouse-Watson 2013, 2016, 2019). Our research on news media of an equally visible rape complaint, involving a global celebrity footballer, was focused on identifying patterns of themes articulating power ideologies that tended to dismiss the allegations, highlight the seriousness of the allegation and neutralize sexual victimization. On a first level of analysis we found ten sub-themes that could then be aggregated into these three critical themes. In general, the reporting mostly ignored any contextualization, let alone issues of gender and of power balance between the complainant and the Portuguese athlete. Most of the reporting adopted the "events-based" emphasis of news reporting (Kitzinger 2009), as well as the focus on controversial allegations, relying on legal actors discourse, or focusing on unintended or collateral consequences for the economy of Ronaldo's clubs. Because the case had not yet reached the courts at the time our research took place, we could not go beyond the impacts of the revelation of a complaint against the athlete. However, these impacts were immediately observed in the news media public sphere which mostly stressed the improbability of the allegations and indeed Ronaldo's generally unambiguous celebrity status.

Issues such as lack of awareness of how race, class, and celebrity status are factors that influence why certain testimonies are more likely to be heard and believed (Zarkov and Davis 2018). What our research shows is how the celebrity halo of a celebrity football player can also compromise a serious and ethical coverage of a rape allegation.

Finally, the events can be related to the national impact of \#MeToo movement on understandings of power and emancipation. As in most of the western world, the \#MeToo campaign received a considerable amount of media attention in Portugal. However, its impact is hard to evaluate. While the movement has been galvanizing for many (Mendes, Jessica, and Keller 2019) feminist scholars nonetheless have concerns about its unfolding and this case highlights why these concerns are relevant.

Regardless of the future outcome of this legal case, feminist theory may benefit from our insights into the definition of rape news themes which can affect public perceptions of both individual rape allegations and of sexual assault in general; their identification is of utmost interest to feminist understandings of rape and to broader ideas of the impact of the \#MeToo movement in local contexts. In this respect and reminding ourselves of the undeniable force of the feminist \#MeToo movement, reading through the media, one is left with an irony that comes across the news: him too? Indeed, although perhaps as expected, the news focus was on the individual, not on the issue and certainly not on sexual violence as a gendered matter. Considering the high-profile case and its capacity to generate considerable awareness, the news media seem to have lost a good opportunity to highlight rape allegations as a serious matter, pushing to define what should be considered to be newsworthy, regardless of the celebrity status of those involved. 


\section{Notes}

1. Ana Sá Lopes "Santo Ronaldo e as Prostitutas" ("Saint Ronaldo and the prostitutes"), Editorial for Jornal Público on 7 October 2018. The ironic editorial tone depicts the national sports hero status in the context of a problematic sexual national culture. The column is centerd on how the national celebrity was generally defended and the woman scorned, pointing out how this was part of a culture of machismo, cultivated by men and accepted by women, characterizing a country of "deep machismo rooted in vast parts of the female population will take centuries to disappear" (Idem).

2. Spiegel Online "How Ronaldo's Legal Team Dealt with Disaster" 8th October 2018 https://www. spiegel.de/international/how-ronaldo-legal-team-dealt-with-rape-accusations-a-1231779. html.

3. Spiegel Online "Cristiano Ronaldo's Secret" 19th April 2017 https://www.spiegel.de/ international/zeitgeist/der-spiegel-football-leaks-exclusive-cristiano-ronaldo-rape-allegationa-1143910.html.

4. Spiegel Online "The Woman Who Accuses Ronaldo of Rape" 29th October 2018 https://www. spiegel.de/international/cristiano-ronaldo-kathryn-mayorga-the-woman-who-accusesronaldo-of-rape-a-1230634.html.

5. Reuters "Ronaldo lawyers to sue Der Spiegel over 'illegal' report" 29th September $2018 \mathrm{https} / / /$ www.reuters.com/article/us-soccer-ronaldo/ronaldo-lawyers-to-sue-der-spiegel-over-illegalreport-idUSKCN1M90KY.

6. Jornal de Notícias "Advogados de norte-americana vão explicar queixa de violação contra Cristiano Ronaldo" 2th October 2018 https://www.jn.pt/desporto/canal/planeta-ronaldo/ advogados-de-norte-americana-vao-explicar-queixa-de-violacao-contra-cristiano-ronaldo9938229.html.

7. Spiegel Online "Cristiano Ronaldo's Secret" 19th April 2017 https://www.spiegel.de/ international/zeitgeist/der-spiegel-football-leaks-exclusive-cristiano-ronaldo-rape-allegationa-1143910.html.

8. https://www.skysports.com/football/news/11667/2356228/no-charges-for-ronaldo.

9. According to data from Associação Portuguesa de Controlo de Tiragens e Circulação, the Portuguese Association which measures newspapers prints and circulation.

10. The ten initial themes were: Ronaldo social high life; Ronaldo as a national hero; Ronaldo is innocent; economic consequences; collateral damages; trivializing the allegations; women scorned/ scrutiny of the complainant; complainant vulnerability; scrutiny of the accused; and deconstruction of rape myths.

11. Marialva is a term somewhat equivalent to macho.

\section{Disclosure Statement}

No potential conflict of interest was reported by the authors.

\section{ORCID}

Maria João Silveirinha (1D) http://orcid.org/0000-0002-0702-3366

Rita Basílio Simões (D) http://orcid.org/0000-0001-6356-6042

Thâmara Santos (i) http://orcid.org/0000-0001-9605-0560

\section{References}

Alcoff, L. M. 2018. Rape and Resistance. Cambridge: Polity Press.

Ardovini-Brooker, J., and S. Caringella-MacDonald. 2002. "Media Attributions of Blame and Sympathy in Ten Rape Cases." The Justice Professional 15 (1): 3-18. doi:10.1080/08884310212826. 
Baker, K. K., and M. Oberman. 2016. "Women's Sexual Agency and the Law of Rape in the 21st Century." In Special Issue: Feminist Legal Theory. Vol. 69, 63-111. doi:10.1108/S1059433720160000069003.

Benedict, H. 1992. Virgin or Vamp: How the Press Covers Sex Crimes. Oxford: Oxford University Press.

Cuklanz, L. 1996. Rape on Trial: How the Mass Media Construct Legal Reform and Social Change. Philadelphia: University of Pennsylvania Press.

Franiuk, R., J. L. Seefelt, S. L. Cepress, and J. A. Vandello. 2008. "Prevalence and Effects of Rape Myths in Print Journalism: The Kobe Bryant Case." Violence Against Women 14 (3): 287-309.

Gans, H. 1979. Deciding What's News: A Study of CBS Evening News, NBC Nightly News, Newsweek and Time. New York: Vintage.

Gray, J. M. 2015. "What Constitutes a 'Reasonable Belief' in Consent to sex? A Thematic Analysis." Journal of Sexual Aggression 21 (3): 337-353. doi:10.1080/13552600.2014.900122.

Hall, S., C. Critcher, T. Jefferson, J. Clarke, and B. Roberts. 1978. Policing the Crisis: Mugging, the State, and Law and Order. London: MacMillan Press.

Harrington, C. 2016. "Feminist Killjoys and Women Scorned: An Analysis of News and Commentary on the Sexual Violence Allegations Against Julian Assange." Feminist Criminology 13 (1): 87-111. doi:10.1177/1557085116646194.

Hjarvard, S. 2010. "The Views of the News: The Role of Political Newspapers in a Changing Media Landscape." Northern Lights 8: 25-48.

Horvath, M. A. H., and J. M. Brown. 2009. "Setting the Scene: Introduction to Understanding Rape." In Rape: Challenging Contemporary Thinking, edited by M. A. H. Horvath, and J. M. Brown, 1-14. Cullompton: Willan Publishing.

Jorge, A. 2015. "'Cristiano Ronaldo is Cheap Chic, Twilight Actors are Special': Young Audiences of Celebrities, Class and Locality." Celebrity Studies 6 (1): 39-53. doi:10.1080/19392397.2015.995467.

Keller, J., K. Mendes, and J. Ringrose. 2018. "Speaking 'Unspeakable Things': Documenting Digital Feminist Responses to Rape Culture." Journal of Gender Studies 27 (1): 22-36. doi:10.1080/ 09589236.2016.1211511.

Kitzinger, J. 2009. "Rape in the Media." In Rape: Challenging Contemporary Thinking, edited by M. Horvath, and J. Brown, 74-98. London: Willan Publishing.

Lawless, B., and Y.-W. Chen. 2019. "Developing a Method of Critical Thematic Analysis for Qualitative Communication Inquiry." Howard Journal of Communications 30 (1): 92-106. doi:10.1080/ 10646175.2018.1439423.

Mendes, K., R. Jessica, and J. Keller. 2019. Digital Feminist Activism. Girls and Women Fight Back Against Rape Culture. Oxford: Oxford University Press.

Meyers, M. 1997. News Coverage of Violence Against Women: Engendering Blame. London: Sage.

Nilsson, G. 2018. "Rape in the News: On Rape Genres in Swedish News Coverage." Feminist Media Studies, 1-17. doi:10.1080/14680777.2018.1513412.

Nyúl, B., A. Kende, M. Engyel, and M. Szabó. 2018. “Perception of a Perpetrator as a Successful Person Predicts Decreased Moral Judgment of a Rape Case and Labeling it as Rape." Frontiers in Psychology 9: 2555. doi:10.3389/fpsyg.2018.02555.

O'Hara, S. 2012. "Monsters, Playboys, Virgins and Whores: Rape Myths in the News Media's Coverage of Sexual Violence." Language and Literature 21 (3): 247-259. doi:10.1177/0963947012444217.

Reinharz, S. 1992. Feminist Methods in Social Research. New York: Oxford University Press.

Reynolds, P. 2015. "Women's Agency and the Fallacy of Autonomy: The Example of Rape and Sexual Consent." In Women and Violence: The Agency of Victims and Perpetrators, edited by H. Marway, and H. Widdows, 197-215. London: Palgrave Macmillan UK.

Royal, K. 2019. "An Analysis of a High-profile Rape Trial: The Case of UK Footballer Ched Evans." Journal of Gender-Based Violence 3 (1): 83-100. doi:10.1332/239868019X15475689978131.

Silveirinha, M. J., and R. Simões. 2019. Making (no)sense of Rape Culture in social media: Across the borders of the sexist status quo into women's sexual agency. Paper presented at IAMCR 2019, Marid.

Soothill, K., and S. Walby. 1991. Sex Crime in the News. London: Routledge.

Temkin, J., J. M. Gray, and J. Barrett. 2016. "Different Functions of Rape Myth Use in Court: Findings From a Trial Observation Study." Feminist Criminology 13 (2): 205-226. doi:10.1177/ 1557085116661627. 
Tuchman, G. 1978. Making News: A Study in the Construction of Reality. New York: Free Press.

Waterhouse-Watson, D. 2013. Athletes, Sexual Assault and 'Trials by Media': Narrative Immunity. New York: Routledge.

Waterhouse-Watson, D. 2016. "News Media on Trial: Towards a Feminist Ethics of Reporting Footballer Sexual Assault Trials." Feminist Media Studies 16 (6): 952-967. doi:10.1080/14680777. 2016.1162827.

Waterhouse-Watson, D. 2019. "Who Is the 'Real' Victim? Race and Gender in the Trial of an Elite Australian Footballer." In Rape Narratives in Motion, edited by U. Andersson, M. Edgren, L. Karlsson, and G. Nilsson, 147-169. Cham: Springer International Publishing.

Weiss, K. G. 2011. "Neutralizing Sexual Victimization: A Typology of Victims' Non-reporting Accounts." Theoretical Criminology 15 (4): 445-467. doi:10.1177/1362480610391527.

Zarkov, D., and K. Davis. 2018. "Ambiguities and Dilemmas Around \#MeToo: \#ForHow Long and \#WhereTo?" European Journal of Women's Studies 25 (1): 3-9. doi:10.1177/1350506817749436. 